\title{
FLASHES EM CIRCUITO
}

\author{
Ivete Lara Camargos Walty \\ PUC-Minas
}

\begin{abstract}
RESUMO
Reflexão sobre o papel da narrativa urbana no tratamento do tema da exclusão social, tendo como ponto de partida uma leitura do livro Passaporte, de Fernando Bonassi, que envolve a discussão do próprio gênero, a partir, sobretudo, da teoria do conto de Ricardo Piglia e de sua retomada das Seis propostas para o próximo milênio, de Ítalo Calvino, em artigo recente.
\end{abstract}

\section{PALAVRAS - CHAVE}

Fernando Bonassi, narrativa urbana, exclusão social.

$\mathbf{E}_{\mathrm{m}}$ "Teses sobre o conto", Ricardo Piglia (1987) postula que "um conto sempre conta duas histórias". Discutindo as formas sob as quais tal postulação ocorre, mostra que Borges teria feito da construção cifrada da segunda história o tema principal dos contos, reproduzindo "a busca sempre renovada de uma experiência única que nos permite ver, sob a superfície opaca da vida, uma verdade secreta". Citando Rimbaud, fala de: "A visão instantânea que nos faz descobrir o desconhecido, não numa longínqua terra incógnita, mas no próprio coração do imediato", e conclui: "Essa iluminação profana se transformou na forma do conto".

Lendo os minicontos de Fernando Bonassi, no livro Passaporte (2001), perguntei-me sobre essa questão das duas histórias discutidas por Piglia, tendo como referencial uma outra questão que ora move minhas reflexões: configurações do excluído na narrativa urbana. Dessa forma, meu próprio texto se articularia a partir de duas histórias: a literária e a político-social. Observe-se, no entanto, que essa dualidade, em qualquer um dos casos, merece ser discutida com mais vagar, dada a complexidade que envolve.

Vale a pena começar pelo suporte, que vai da precariedade do jornal diário, de onde alguns relatos são extraídos para a nova publicação, a um livro que, não por acaso, se chama Passaporte (relatos de viagem). O livro, à moda de um passaporte oficial brasileiro, agrupa 137 textos, com 10 a 15 linhas, que, na verdade, correspondem à metade de uma linha em lauda normal. São, pois, minitextos, datados, porém não linearmente, que, em primeira instância, referem-se sempre a um espaço determinado. Tempo e espaço são, no entanto, relativizados, de forma a que estes textos apresentem-se como nós de uma rede viária, podendo ser lidos, por isso mesmo, em qualquer ordem; não há centros ou hierarquias.

Em virtude do que se quer privilegiar, busquei analisar mais detidamente os contos que se ambientam nas grandes cidades brasileiras, o que não significaria deixar de lado os outros, ocultando faces fundamentais de viagens metafóricas e literais e histórias transnacionais. Ocorreu, por outro lado, que a tentativa de se separarem os contos ambientados no Brasil, e mais especialmente nas grandes cidades, foi malograda em função 
da radiação que caracteriza os textos, marcados por elementos que, como em curto-circuito, se conectam intermitentemente.

Não por acaso, o primeiro texto chama-se "radial leste" e fala de mortes anônimas, mortes estas que constroem um vetor de leitura, que, paradoxalmente, impossibilita a separação entre cidade e campo, cidade e vila, Brasil, México ou Alemanha, complicando de início minha proposta de leitura. Vale lembrar a força contida na palavra "radial": aquilo "que emite raios", "que é análogo a um raio". A despeito da precisão técnica da palavra no contexto urbanístico, em sua referência a uma via que vai do centro à periferia, não se pode deixar de lado a idéia de irradiação de luz e energia, o que ressalta a significação de rede, de processo em curso.

Assim, a estrada/vetor abre-se tanto para Jiparaná, no Brasil, como para Munique, na Alemanha, tanto para o momento atual como para a história da colonização, tempos que, na verdade, não se opõem, mas se iluminam. O morto anônimo é ora o índio desdentado ou corno, ora o moleque alemão que morre vítima do "snow board", ou o polonês, vítima da história. Seriam todos protagonistas de histórias de colonização, histórias de crucificação, que, como se vê pelo título, se irradiam pelo livro/mundo.

No conto intitulado "crucificação" (011), por exemplo, a história utilizada para contar outras não é cifrada, é manifesta do título às citações; também não são cifrados os espaços que se desenham: "De um lado o horizonte dos petroleiros, de outro, as senhoras de bens catando lixo na floresta com medo de cobra. Macumbas derretem e grudam nas pedras pichadas. Banhistas na sua, em torno, no sol". Mas não se pense que se trata apenas da divisão de classes, pois, mais que de divisão, fala-se de mistura de desejos, de grupos, de culturas e muito mais: "Cinco guardas de barriga aparecem com três garotos desossados. Perfilados e bronzeados piscam sem parar, sem camisa. $O$ traficante chega de Civic, pergunta pelos 30 dinheiros, dá um tiro em cada palma de mão e vai embora." A ambigüidade não deixa que separemos as "senhoras de bens" do traficante de Civic; os guardas dos garotos ou o Cristo do Judas e seus 30 dinheiros. O deslocamento da expressão "de bem" para "de bens" vai além da paródia, na medida em que não fixa os espaços. Olhares vagam sobre as pessoas e as coisas, sem se fixar, como se pousassem nos corpos vivos/mortos, que tanto podem ser o corpo literal como o metafórico, envolvendo aspectos econômicos, culturais, políticos, históricos e míticos.

Em "a besta humana" (109), por exemplo, o olhar de uma criança volta-se para o "olho vidrado" da servente da escola, que "foi andar na linha de trem" e "estourou como um balão”. O grotesco da cena é atribuído ironicamente pelo narrador ao exagero próprio da infância. Os pedaços do corpo associam-se diretamente aos pratos vazios das crianças da escola. Não há como deixar de associar a servente aos cães suicidas do segmento (019), em que o narrador transmite ao leitor o convite da personagem: "Almir insiste pra observarmos os cães mortos na estrada". Os olhares deslocam-se por espaços e tempos diferentes, possibilitando a indagação: seriam todos crucificados como os mortos da Radial Leste (001), anunciados nas cruzes sem nome?

A imagem da morte configura-se, por vezes, na do fogo que, como no caso das queimadas tão costumeiras no norte e no centro-oeste, "cruzam a estrada e fazem esculturas deformadas no asfalto", desafiando os motoristas e os habitantes da cidade. "Mas todos voltam logo depois, trazendo seus corpos inflamáveis, vestindo roupas inflamáveis, erguendo casas inflamáveis... até a próxima vez." (Coxim - 1987). A densidade da fumaça ocorre, 
mais que no plano do enunciado, na construção narrativa, também ela oscilante entre a opacidade e a iluminação. A imagem das "galinhas ensangüentadas que corriam como tochas pela paisagem", após o acidente na estrada Belém-Brasília, não difere das anteriores, assim como o "cogumelo de fumaça negra, (que) "brotou da estrada ao longe" (028), não difere do cogumelo radioativo em Hiroshima. Tudo são "paisagens com galinhas queimadas".

O texto "Pura repetição" (050) referenda tal leitura quando coloca o fogo como traço comum entre dois homens num terreno baldio. Não há espírito de vingança ou de solidariedade, apenas: "Um dos homens levanta e joga um pedaço de caixote dentro do tambor. Voam faíscas. Uma delas queima o braço do outro homem, sentado. O homem não grita. O homem queimado levanta. Joga um pedaço de caixote na fogueira. Voam faíscas. Uma delas queima o braço do outro homem, que se sentara. O homem não grita. Vários carros passam na estrada. Noite.” (Mogi das Cruzes - 1994).

A estrutura reiterativa da narrativa promove a troca dos sujeitos/objetos desnomeados, que, de resto, referem-se a vivências comuns na sociedade atual.

O corpo fragmentado, marcado, é, pois, figura reiterada nas narrativas também fragmentadas. Vejam-se, por exemplo, os textos "física elementar" (122) e "pulmões" (123), em que os narradores, respectivamente um passageiro de ônibus em Volta Redonda e um narrador anônimo em Berlim Ocidental, se descrevem em seu estar no espaço físico. Das poucas narrativas em primeira pessoa, estas radiografam o corpo humano, ultrapassando o plano fisiológico, ao exibi-lo. No primeiro, "vértebras", "vísceras", processo digestivo; no segundo, "pulmões inteiros" e, como diz o narrador: "Minha humanidade reduzida às suas carnes".

Em "os indolores" (022), explicita-se o processo de exposição do corpo objeto, desvestido de humanidade, através da referência à ausência de dor característica da família de Pietro, em Praga. "Ficam semanas com ossos quebrados, tumores supurados e raízes dentárias expostas sem se darem conta. (...) Não podem entender essa cara estranha, entre enjoada e triste, que as pessoas fazem quando sentem tais coisas". O corpo, desfeito nos elementos que o compõem ou naqueles que excreta, não se faz fator de identidade humana, como "uma porção de espaço, com suas fronteiras, centros vitais, defesas e fraquezas, sua couraça e defeitos", conforme mostra Marc Augé ${ }^{1}$, ao falar de seu papel em sociedades tradicionais. Da mesma forma, em "primeira geração" (024), a figura da personagem Milton, de testa pontuda em virtude do parto por fórceps, imitando os bichos do "Discovery Channel", exibe o corpo humano nos deslimites de suas funções: "Vinte e quatro horas de uivos, grasnados, latidos e pios estão além do que mesmo a barra pesada de Brixton pode suportar". Ressalte-se, no caso, a intermediação da mídia, no processo repetidor, misturando realidade e ficção, gente e bicho, loucura e sanidade.

A sujeira é outro vetor de leitura ligado ao da morte e do corpo em decomposição, que coloca em causa o caráter humano. Vale lembrar José Carlos Rodrigues (1995) quando ressalta a analogia entre morte e lixo e entre este e a idéia de ameaça à ordem, já tão estudada por outros antropólogos. No texto "turismo ecológico" (003), tal idéia vem associada ao processo de colonização em seu aspecto de limpeza e ordem: "Os missionários chegaram e cobriram das selvagens o que lhes dava vergonha. Depois as fizeram decorar a ave-maria, a manter a higiene, e lhes arranjaram empregos nos hotéis da floresta, onde se

${ }^{1}$ AugÉ. Não-lugares: introdução a uma antropologia da supermodernidade, p. 59. 
chega de uísque em punho." (Cuiabá - 1995). Mas, à revelia do controlador, os resíduos voltam e se instalam na "nova civilização", em forma da mistura de corpos, da troca das secreções corporais: "Haveria uma lógica humanitária exemplar no negócio, não fosse o fato de as índias começarem a deitar-se com os hóspedes". Observe-se que tal troca fica mais evidente no segmento de número 005, intitulado "pró-álcool"; também aí com a idéia de progresso, de civilização, só que já acompanhada pela sujeira: "Primeiro derrubaram as árvores que faziam a cortina com Ribeirão Preto e espetaram os tubos das usinas no lugar. Depois chegaram as moscas verdes. Desse tamanho, sujando os pudins. (...) Então os caminhões, largando um rastro de cana morta pela rodovia. É ali que agora as meninas deram pra cuspir filhos de três meses, enquanto as marmitas esperam no acostamento". Aqui corpo e lixo associam-se definitivamente nos fetos abortados que deixam o rastro da morte como a cana das usinas.

O modelo de colonização vai sendo, paradoxalmente, relativizado e ratificado. Por isso mesmo, a figura indígena é personagem de vários textos, em que se estabelece um jogo de espelhos bastante desvelador. Em "índios aprendem depressa" (015), a reiteração do sujeito índios nas frases de ações enfaticamente repetidas evidencia a força irônica do que seria a civilização em sua força prostituidora: "mas os índios aprendem depressa e, se antes davam suas filhas de presente, agora começam a cobrar por isso." O mesmo movimento ratifica-se no segmento 101 "planalto central" (101), em que o índio Wilson Patachó, o índio do Posto Shell, oferece suas filhas aos caminhoneiros. O ritual antropofágico se faz tanto no nível da relação sexual, como no da relação social. A ambigüidade textual inverte a proposta do enunciado, evidenciando o mecanismo de exploração próprio do movimento civilizatório: "Cibele tem todos os dentes, Pamela não tem nenhum e, justamente por isso, é a preferida pra coisa que aqueles homens brancos gostam mais de fazer". Observe-se que, embora, em primeiro plano, a ação seja da índia, desdentada, em outro plano, o sujeito da frase são os homens brancos, que gostam de praticar esse tipo de ação. Remete-se ao mito da vagina dentada pelo seu avesso, na medida em que se ressalta o ato de sugar o outro.

Um outro contraponto desse jogo civilizatório e seu ritual antropofágico é o segmento 087, "breve relatório de uma recepção inesquecível", em que, pelo mesmo sistema de repetição enumeratória, há referências a um mundo de "outros caciques", marcado por produtos de consumo de várias partes do mundo: "copos da Boêmia”, 'sachê de Issey MacQueen”, "alças dos Victoria Secret” ou charutos cubanos. O jogo ambíguo mistura mundos através da figura do cachimbo: "Naquele quarto especial, sob luz negra, todos aspiram a ser ainda melhores coisas. Muito cacique tranqüilo abocanhando saudosas Havanas. Milhões de índios antropófagos a quilômetros de distância trocam os primeiros sinais de fumaça". (São Paulo - Brasil - 1997). Outra vez a força dos sentidos, dessa feita, conotada pelos verbos aspirar e abocanhar, em suas várias significações. Várias histórias podem ser lidas nesse pequeno fragmento feitos de fragmentos, todos eles marcados pelo movimento antropofágico. Assim, descrevendo-se índios, operários, metalúrgicos, executivos, traficantes ou macumbeiros, descrevem-se mecanismos de sistemas político-sociais e econômicos pautados pelo canibalismo, de corpos, força de trabalho ou desejos. Daí a idéia de ritual, também sempre evocada, como se vê no texto que tem como título: "ritos de passagem", em que a personagem transita entre a identidade xavante e a que lhe fora conferida na civilização: "Os paulistas, inconformados, não sabem que ele deixou de ser 
xavante sem ficar homem. Por isso, nos sonhos, é sempre devorado." (055) A busca de reinserção em seu meio, através do ritual em que se fica "um dia inteiro com o braço direito no tronco cheio de formigas”, num movimento de aproximação com as feras, mostra que, na verdade, muitos são os rituais e muitas as feras, pois tudo são passagens, tudo são escatologias. Daí a força da imagem da morte, como vem sendo acentuado.

Vários são os textos que levam no título a expressão natureza-morta, associando a forma pictural à realidade social brasileira, que, à maneira de aquarelas ao avesso, exibemse ao leitor/espectador. "natureza morta com tamanduateí (071)" nos permite evocar cena já antológica do romance Cidade de Deus, de Paulo Lins, em que um riozinho passa, levando detritos e corpos: "Sofás, pneus, cadáveres esquisitos em posição de estilo passam boiando emplastrados de detritos. Peixes pré-históricos perdidos há muito tempo navegam ao lado de dragas revoltadas. Jacarés chorando químicas lágrimas de crocodilo. Uma água pesada encrencando moinhos que nem duras greves de ABCs salvariam; por onde qualquer Jesus pregado passa na corrida." Os trocadilhos, não sutis, ressaltam a mistura que vem caracterizando a narrativa móvel, que, por sua vez, quer-se metonímia da "América latrina", poço de detritos, orgânicos e inorgânicos, de sujeitos e objetos. Se se fica apenas em um plano, explicita-se o caráter de alegoria tradicional, em que uma história conta outra, em que um quadro exibe outro, o que, de resto, é desvelador da realidade brasileira. Se, no entanto, continua-se a leitura, vê-se que os mecanismos de salvação, políticos ou religiosos, são invalidados e o lixo é a matéria por excelência, do texto e da sociedade. E é o lixo que circula na superfície do texto e da sociedade que impede o olhar dicotômico, com que geralmente a sociedade pede para ser lida: de um lado os pobres, sujos, ameaçadores; de outro, as pessoas de bem, responsáveis, honestas, respeitáveis.

Em "natureza morta com são paulo" (051), o sistema de enumeração deixa à vista a impossibilidade de saída. "Gatos com ratos mortos na boca. Ratos mortos com formigas na boca. Crianças chorando abertamente. Homens-feitos chorando escondidos. Talheres raspando pratos. Televisão no fim. Camas suspensas por latas de óleo. Rostos em terror espiando nos vitrôs. (...)”. A idéia de continuidade, acentuada pelo uso do gerúndio e da preposição com, estranhamente, leva à idéia de fim, através sobretudo da repetição do advérbio de negação nem: "Nem pomada. Nem foda. Nem droga. Nem preguiça. Nem um saco de lixo pra chutar." O lixo não está armazenado em sacos, mas espalhado, exibindo-se.

É interessante observar que, como postula Rodrigues², haveria "uma espécie de grade, espalhada sobre o mundo, estabelecendo nele diferentes domínios, lotes, territórios, que, saídos de uma indistinção original, passam agora a significar por contrastes recíprocos". Dessa forma, os elementos intersticiais da grade seriam "coisas que desafiam o sistema de classificação, por estarem sobre uma linha de separação de categorias ou por serem passíveis de enquadramento simultâneo em duas ou mais delas" (p. 79). Por essa linha de raciocínio, como bem o mostra De Certeau (1994), esses espaços marginais, vistos como sujos e ameaçadores, guardariam novas formas de vida, outros sistemas possíveis. Ocorre que, nas narrativas em questão, o lixo está em trânsito, o espaço está em movimento, são rios, estradas e estações, não-lugares, que, como postula Marc Augé3, "são espaços constituídos em relação a certos fins (transporte, trânsito, comércio, lazer)”.

\footnotetext{
${ }^{2}$ Rodrigues. Higiene e ilusão: o lixo como invento social, p. 75.

${ }^{3}$ Augé. Não-lugares: introdução a uma antropologia da supermodernidade, p. 87.
} 
Vale, então, nos perguntar como se situam aí elementos escatológicos e cosmogônicos e se a narrativa, em lugar de ritual de purificação, agiria como um desmanche do ritual. Dito de outra forma, a narrativa, antes de se colocar como ritual renovador, criando cosmos, mostra-se como caos. Como o próprio corpo, visto como entroncamento, "os relatos de espaço" iriam além do que postula De Certeau, na medida em que não apenas contaminam a malha, mas a desfiam, ou deixam ver seu desfiado, mostrando que não apenas os limites são sujos. Assim, do ponto de vista dos olhares textuais, desmancha-se a lógica binária descrita por Rodrigues: uma sociedade higienizada é uma sociedade hierarquizada e quanto mais do centro do poder, mais distante da sujeira, e quanto mais periférica em relação ao centro, tanto mais íntima com a sujeira. É que, como ele mesmo diz, o conceito de sujeira não é unívoco, mas plural. E a narrativa de Bonassi vem utilizando essa pluralidade, relativizando dicotomias.

A comparação de mais alguns contos pode ser útil na ratificação do desmanche das fronteiras. "os farofeiros" (083), como o título já indica, descreve cenas comuns no dia-adia brasileiro: "Um caminhão fervendo, coberto de lona, carregado de desejos, preces \& frangos assados em cem sóis (...). Aquele perigoso banho de mar entre cacos de vidro e nacos de cocô. Por fim, empurrada por Coca-Colas quentes, macarronada gelada é crocante. Tudo nessas areias beges, como o mais chutado dos pós de vidro" (São Vicente - 1994). A imersão de uns na sujeira faz emergir os cacos e os detritos do todo, pondo em causa sua identidade. Através do sexo, do alimento e dos dejetos, um corpo iguala-se a outro, e, num movimento de tanatologia, transpõe as linhas demarcatórias do limpo e do sujo, do civilizado e não-civilizado.

O texto "Supermercado" (093) poderia ser visto como outra versão dos farofeiros: "Outro mês de salário de fome e cá estamos nós maridos \& mulheres, empurrando carrinhos feito escravos". As relações domésticas se imiscuem nas públicas quando são exibidas no cenário ideal da contemporaneidade, com "meia dúzia de palavras entre as gôndolas e nossa política e café-com-leite magro termina em pizza congelada”. O código alimentar iogurtes, filés macios, sacos de feijão - absorve o sóciopolítico, o psíquico, e termina, biologicamente, no escatológico: "Papel higiênico compramos no atacado. Esse mundo é muito sujo." (São Paulo - 1996). Os jogos de palavras são mais do que irônicos, pois processam na enunciação aquilo que expressam no enunciado, superando os limites deste, assim como alargam as paredes do supermercado, fazendo-as abarcar o mercado sóciopolítico.

Veja-se, por outro lado, o relato 033, "merda e pessoas I", que se passa em Dortmund, na Alemanha. "Peter não quis mais morar perto da via férrea, quando soube que os banheiros dos trens simplesmente despejavam nos trilhos tudo o que os passageiros faziam." A idéia de passagem é evidente no espaço da via férrea, contínua, mas fixa. Assim, no mapa tradicional de uma cidade, ou de uma narrativa, esse seria o lugar da merda, da sujeira. Mas, no texto em questão, Peter busca 'alguma sujeira'. "Nunca achou nada, o que não o faz desistir da mudança. Ele acha suficiente o fato de 'termos de agüentar a nossa própria merda nessa vida." A sujeira, a despeito de não encontrada, ou por isso mesmo, está em toda parte. O relato "merda e pessoas II" parece realçar o significado positivo do elemento escatológico, ao registrar o testemunho do lavrador que manipula o esterco: " Não é um serviço muito limpo ou perfumado', argumenta, 'mas se nós também fazemos isso a gente 
se acostuma."'. No entanto, a ambigüidade do pronome demonstrativo isso desmancha as fronteiras do corpo e do texto, realçando-os como produtores de sujeira.

O texto "descanso diário" (067) ilustra, mais uma vez, a relatividade das fronteiras, através da figura do justiceiro, que protege os comerciantes. Em seu corpo misturam-se alimentos e sangue de terceiros: "Um saco de leite chacoalhando sem bolas, dois pães quentinhos no sovaco. Um resto de perfume entre os pêlos. Sangue de três coagulado sob as unhas, que limpa co'a ponta de uma tesoura ao acaso. Pólvora vitrificada nas palmas, como maquiagem de crucificação". Observe-se a referência aos sentidos: visão, olfato, tato e paladar, ligados à idéia da sujeira trazida nos detritos e da limpeza buscada com furor: "Toma um banho daqueles. Esfrega-se tanto na bucha, mas tanto na bucha, que se diria de si”. A ambigüidade da última frase, depois da inversão do processo de limpeza em que se passa de sujeito a objeto, na medida em que se esfrega na bucha, ao invés de esfregar a bucha em si, põe em causa a possível consciência do agente da morte.

A descrição de um pronto-socorro em um sábado à noite (096), com uma referência ao poema "Porque hoje é sábado", de Vinicius de Moraes, exibe outra face da história anterior, trazendo para a cena outras personagens - enfermeiras e médicos, hierarquicamente colocados - mantendo as primeiras na figura das facas e revólveres, do sangue esvaído na poeira, do xixi a ser enxugado. O espaço e os corpos se fundem na dor em suas inúmeras faces, deixando ver que as regras que os regem são as mesmas: "Todo esse sangue esvaído na poeira está perdido pras transfusões. Pai \& filhos da mãe aguardando transferências, se der o tempo dela. Rins artificiais com ferrugem saindo no xixi que uma enfermeira malhada enxuga, além de médicos de oitocentos paus que não podem ser pra todas obras."

Em "reunião de condomínio" (074), a enumeração de pessoas, animais, e objetos "peruas preocupadas", "treze senhoras de alta estima”, golpes do baú”, "bolsas de valores" - faz processar a mistura de que vimos falando, ao mesmo tempo em que exibe as fronteiras sociais, marcadas por muros e cercas. A casta descrita interroga-se sobre os limites que os separam dos outros: "Garoto da pizza fica é na portaria, sem televisão. Qualquer problema a gente sobe o muro e espeta grade!”.

A já tão desgastada expressão "brasil, país do futuro" (048), que dá título a outro conto, esfacela-se na enumeração caótica dos acessórios dados como modernos: marcapasso, microship, celular e cocaína. Os portões sofisticados se abrem para dar passagem à encomenda: "O homem entra, acompanhado pelas câmaras do circuito interno de TV até a porta de casa. A encomenda, 80\% de pureza, chega 10 minutos depois." A impureza do pó exibe a impureza do sistema em suas várias facetas, desvelando o que há também detrás dos muros.

Vê-se, pois, que o excesso de muros e fossos ressalta, paradoxalmente, a relatividade desses mesmos muros e fossos. Assim outros tipos de muros são devassados, como no relato sobre o massacre do Carandiru, "111". Aí a ferocidade dos cães faz-se, mais do que metáfora, alegoria que aponta a ferocidade do sistema. O fato histórico reveste-se de mito: "Haja o que houver a que tempo for será a noite mais preta de todas as noites negras em que os Deuses das chances dormem, pesadamente e sobrevoam corvos insanos dos piores Demônios do Brasil, terra de contrastes e chacinas convocando a face carcomida da morte violenta dentes à mostra (...)". Mas a natureza mítica do texto não lhe alivia o aspecto sóciopolítico e o tom de denúncia, o que, aliás, merece reflexão mais detalhada. A face carcomida da morte, ora na imagem dos corvos ou nos dentes à mostra, ora na alma no esgoto ou nas 
nucas explodindo "feito ovos", por se apresentar miticamente, não exime o país de responsabilidade, o que seria bastante cômodo.

Nesse sentido, há que se realçar que o fato de as narrativas se contaminarem, aproximando tempos e espaços diversos, não têm a propriedade de isentar responsabilidades, aliviando a consciência do leitor. A configuração móvel dos espaços não os iguala, o que seria simplificador e idealizador. As paisagens desenhadas nos textos e pelos textos, a despeito dos vetores em interação, permitem-nos vislumbrar processos sóciopolíticos, mapeando cultura e poder, como propõe Sharon Zukin ${ }^{4}$, em sua discussão do conceito de paisagem. Mas quando a autora propõe que à mobilidade social corresponde maior poder, assim como Rodrigues ${ }^{5}$ afirma que o poder se situa longe da sujeira, a referência é um mundo mapeado do ponto de vista da organização social vigente. $O$ que os contos de Bonassi evidenciam é o embaralhamento de tais equações, já que a sujeira estaria em constante deslocamento, atingindo as áreas de poder constituído.

Nesse sentido, vale lembrar Vera da Silva Telles ${ }^{6}$ quando, usando o conceito de paisagem utilizado por Flora Sussekind ${ }^{7}$, discorre sobre a naturalização da pobreza no Brasil. Diz a socióloga:

(...) Num registro ou no outro, a pobreza é encenada como algo externo a um mundo propriamente social. Fruto de exclusões múltiplas, parece armar um cenário no qual desaparece como problema que diz respeito aos parâmetros que regem as relações sociais. Nessas formas de encenação pública, a pobreza é transformada em paisagem que lembra a todos o atraso do país, atraso que haverá de ser, algum dia, absorvido pelas forças civilizatórias do progresso. Paisagem que rememora as origens e que projeta no futuro as possibilidades de sua redenção, a pobreza não se atualiza como presente, ou melhor, na imagem do atraso, aparece como sinal de uma ausência.

Como paisagem, essa pobreza pode provocar a compaixão, mas não a indignação moral diante de uma regra de justiça, que tenha sido violada. ${ }^{8}$

Embora a autora esteja falando de uma época anterior à que ora se analisa, a longa citação se justifica, na medida em que nos ajuda a refletir sobre o movimento contrário a este realizado nos textos de Bonassi. Se, "transformada em paisagem, a pobreza é trivializada e banalizada", isentando-nos de responsabilidade individual ou coletiva, ao ser exibida como paisagem através de um recorte textual, propõe o sentido oposto. Dito de outro modo: exibe-se a natureza de paisagem dos espaços vinculados à pobreza, levando-se a banalização às últimas conseqüências, de modo que ela irradie suas próprias fraturas e as do sistema que as gera. Observe-se que tal mecanismo é o mesmo que já se registrou nas diversas "naturezas mortas".

Não é sem razão, pois, que os segmentos 131 e 132 não oferecem grandes variações das paisagens que descrevem, intituladas urbanas, no primeiro, e suburbanas, no segundo. A presença da carteira de identidade, nos dois, é bastante reveladora, na medida em que permite ao leitor verificar sua precariedade, tanto maior quanto mais se associa à iminência da morte.

\footnotetext{
${ }^{4}$ ZuKIN. Paisagens urbanas pós-modernas: mapeando cultura e poder.

${ }^{5}$ Rodrigues. Higiene e ilusão: o lixo como invento social.

${ }^{6}$ Telles. Pobreza e cidadania.

${ }^{7}$ Sussekind. O Brasil não é longe daqui.

${ }^{8}$ Telles. Pobreza e cidadania, p. 32.
} 


\begin{tabular}{|l|l|}
\hline \multicolumn{1}{|c|}{ Paisagem urbana } & \multicolumn{1}{|c|}{ Paisagem suburbana } \\
\hline “(...) O homem se afasta sem pagar as & "Sob a luz amarela que o boteco manda, tá \\
contas. Ave-maria entredentes, aperta o & lá um corpo estendido no chão. Mal \\
RG e se atira na frente de um carro (vai & ajambrado sobre a calçada, dedilha porcarias \\
sobreviver a essa aventura). Três palavrões. & na valeta. Há muito tempo, um RG amar- \\
Duas fraturas. Prejuízos variados.” (São & $\begin{array}{l}\text { fanhado identifica uma data de coisas, como } \\
\text { pais ausentes e a terra natal aonde nunca } \\
\text { Paulo - Brasil - 2000) }\end{array}$ \\
\hline
\end{tabular}

Os seres, desnomeados na grande cidade, marcam-se paradoxalmente pela presença de uma carteira de identidade e a idéia da impossibilidade de volta às origens. Acentue-se ainda a idéia de silêncio, marcando a ausência de voz, a impossibilidade da identidade diante de uma força maior: "Aos mais vivos (ou preguiçosos), restará não soltar pios que sejam, enquanto fardas varejarem em torno, procurando cápsulas \& perfurações” (132).

Observe-se que os textos de Bonassi acabam por desvelar a realidade a que se refere Vera Telles: "os pobres são aqueles que não têm nome, não têm rosto, não têm identidade, não têm interioridade, não têm vontade e são desprovidos de razão".

Esse caráter anônimo é reforçado na referência aos lugares de trânsito intenso, mas justamente aí extrapola-se o ambiente que seria circunscrito ao pobre, ao excluído, colocado ao lado de outros, em seu constante caminhar. Vale lembrar Marc Augé ${ }^{10}$, quando ressalta que "a mediação que estabelece o vínculo dos indivíduos com o seu círculo no espaço de não-lugar passa por palavras, até mesmo por textos”. Do texto estereotipado e prescritivo que dirige o olhar do viajante, Fernando Bonassi elabora outros textos, que, como outdoors, atraem o olhar do viajante/leitor, incitando-o a deter o olhar e fazer interpenetrar lugares e não-lugares, anonimato e identidade.

Nesse sentido, à enumeração caótica das pessoas na rodoviária (segmento 135) associam-se as malas como lugar da memória ou da desmemória, o que fica mais evidente, no texto em que estas são personagens "malas" (035). Aí malas são metonímias de pessoas e estas são metonímias de situações: "Pilhas de malas são pilhas de almas, são montes de lama." Observe-se que mala, alma e lama são anagramas, o que acentua no nível da escrita a idéia de intercâmbio, de trânsito, de caminho, de deslocamento, do ir e vir, da relativização de limites que caracteriza a sociedade atual. Assim, ao lado dos migrantes transregionais, unindo sul e norte do país, estão os transnacionais, relativizando e/ou ratificando, ao mesmo tempo, os conceitos de exclusão e globalização. Assim como correntes de tecnologia atravessam as fronteiras de países, também correntes de excluídos o fazem. Embaralhando as diferentes correntes, os textos fazem mover o olhar do leitor de uma para outra sem descanso.

Nesse sentido, vale lembrar que, ao se discutir a situação dos excluídos na sociedade atual, os sociólogos refletem sobre sua animalização ou coisificação, como se pode observar

\footnotetext{
${ }_{9}$ Telles. Pobreza e cidadania, p. 42.

${ }^{10}$ Augé. Não-lugares: introdução a uma antropologia da supermodernidade, p. 87.
} 
em Burztyn ${ }^{11}$. Nesse contexto, a exclusão levaria a uma dessemelhança entre os seres humanos, que se transformaria em diferença biológica. Na abordagem de Bonassi, embora se possa perceber tal premissa, processa-se seu desmanche, não porque a situação seria melhor, mas porque aqueles que se crêem em situação melhor ou superior não escapam da coisificação e/ou animalização, que, de resto, marca as relações sociais.

Ressalte-se mais uma vez, porém, que isso não significa a solução dos conflitos ou seu mascaramento, antes o trânsito por diferentes paisagens permite diferentes olhares, ora convergentes, ora divergentes. Veja-se o texto "paisagem com remédios", que, curiosamente, contém no título o termo paisagem, deixando claro o aspecto de visualização e os aspectos já discutidos. Também aí, a relevância é para os detritos, a força da ruína, aquilo que acaba mesmo antes de ser terminado, como se pode ver pelos adjetivos "inacabado", "velhos", "puídos", que unem coisas, animais e pessoas "vira-latas". Mas essa sujeira, própria dos lugares pobres, alcança outro segmento, como a "fumaça de remédios vencidos, conotando a impossibilidade de solução: "gosmentos de vergonha das suas sujeiras, os engenheiros cobrem o Tamanduateí com placas de concreto."O possessivo "sua”, referente às sujeiras, acolhe tanto o rio como os engenheiros, sobretudo se se pensa na construção da "auto-estrada moderníssima", ponte sobre o lixo.

Também aqui, vale evocar Vera Telles, quando, citando Maria Alice Rezende, discorre sobre a "cultura da reforma", que caracterizaria a civilização brasileira:

A modernização aparece como mito de origem que legitima o regime na sua tarefa de construção racional da Nação, de tal forma que essa legitimidade se descola do espaço político dos conflitos por onde foi resolvida a construção republicana nas sociedades modernas. ${ }^{12}$

Observe-se que, ao desenhar a construção da ponte sobre o rio sujo, aponta-se para essa "cultura da reforma" e para sua ineficiência. O lixo encoberto não se conforma dentro dos limites que lhe são estabelecidos, o que indicia os conflitos escamoteados e/ou ignorados. Além disso, a referência a outras mortes anônimas: "Os meninos vão adorar rachar a cabeça nessas pistas lisinhas. Quem viver verá na TV." (São Paulo - 1993) ressalta o lado de espetáculo prenunciado pela TV, que se repete em vários outros textos, como é o caso de "verdades e mentiras", em que se vendem cenas sexuais gravadas em um hotel, sem conhecimento dos agentes. As partes do corpo são grotescamente descritas: "Hoje suas fitas vendem mais que esse 'lixo posado' que se produz por aí, com garotas tentando ser atrizes, cheias de esgares que mais parecem prestes a vomitar, com detalhes de caralhos inchados e bucetas disformes." Ao exibir as partes íntimas do corpo sem nenhum glamour, o conto, em forma de pastiche, aumenta a visibilidade dos costumeiros filmes pornográficos, esfacelando-os como os corpos exibidos. Essa exposição do privado nos remete aos minicontos como flashes de exibição, perfazendo o jogo de mistura entre enunciado e enunciação. Volta-se à idéia discutida por Piglia; o conto seria, pois, uma iluminação instantânea, mas não nos leva a uma verdade secreta, antes a verdades como a mencionada no enunciado conto: "Suas produções têm verdade. Não... ele não acha que esteja roubando nada...

\footnotetext{
${ }^{11}$ BuRzTyn. No meio da rua: nômades, excluídos e viradores, p. 8.

${ }^{12}$ Telles. Pobreza e cidadania, p. 39.
} 
talvez apenas um pouquinho 'dessa verdade' com que pessoas fazem coisas sem saber que estamos olhando." Trata-se do simulacro do simulacro, que borra as margens entre o vivido e o representado, mostrando que tudo está na superfície rizomática, à flor da página, literária, histórica, social, política e/ou mítica.

O fragmento 038 - "mentindo sinceramente" - sintetiza com propriedade esse jogo de representação e exposição, remetendo, aliás, ao próprio mecanismo dos textos de Bonassi. Isso porque, a partir do título, discute-se o valor do documento na escrita da história. $\bigcirc$ álbum de fotografia de William, "verdadeiro documento", é desmanchado e remontado: "casou pares abraçados, matou velhos que desapareciam no meio e fez, das senhoras das últimas páginas, aquelas meninas das primeiras.” Na retomada sempre móvel do álbum, William constrói sua identidade: "Agora mostra o álbum e diz que são seus próprios antepassados. Pra cada um inventa uma história. Afinal todos acabam inventando uma história e, dessa forma, pelo menos, William acredita estar mentindo sinceramente. (Münster - Alemanha - 1998)". A relação entre memória e foto inclui a imagem/escrita, documento montado de uma história de um indivíduo, de uma família, de um país, na construção de identidades múltiplas.

Dessa forma, o conto não conta duas histórias, mas muitas, tantas quantas são possíveis conexões em rede móvel. Se se rompe o continuum da história, na perspectiva benjaminiana, rompe-se o continuum da espécie literária, atomizada, mas em rede. Cada fragmento é um caco de história e da História, o que não invalida nenhuma das duas, antes insere-as em suas tradições e com elas dialoga.

Em artigo mais recente, Piglia, retomando Calvino, postula o que seria a sexta proposta para o novo milênio: "la distancia, el desplazamiento, el cambio de lugar. Salir del centro, dejar que el lenguaje hable también en el borde, en lo que se oye, en lo que llega de otro". ${ }^{13}$

Piglia, postulando que o escritor busca uma outra enunciação que ajuda a narrar, recorre mais uma vez a Rimbaud, e diz que "la literatura sería el lugar en el que siempre es otro el que viene a decir. "Yo soy otro" (p. 3). E preconiza que é através da presença desse outro que se passa da mera informação à experiência. ${ }^{14}$

No caso dos textos de Bonassi, mais do que a duplicação do ato de enunciar, como se viu, tem-se sua pluralização e, justamente, aquilo que aparece como mera informação, marcada pela enumeração exaustiva, ganha estatuto de experiência coletiva. Coletiva porque envolve enunciadores vários, inclusive o leitor, que passa de espectador a participante, na organização do álbum de retratos, que lhe confere identidade, ou viajante, no trânsito pelas radiais e/ou pelas rodoviárias, onde estão "essas malas frágeis de memória arremessadas em gigantescos porta-malas fazendo um eco ensurdecedor que ninguém vai ouvir" (135). Nesse sentido, também as fronteiras entre o literário, o histórico e o políticosocial se fazem móveis, relativizando classificações textuais predeterminadas.

Como os relatos 048 e 049, lado a lado e em seqüência, no livro, mostram diferentes muros: os dos condomínios fechados e os do Carandiru, além das relações de poder que

\footnotetext{
${ }^{13}$ Piglia. Una propuesta para el nuevo milenio, p. 3.

${ }^{14}$ A esse respeito não se pode deixar de evocar Silviano Santiago com seu ensaio "O narrador pósmoderno", em que justamente postula que este faz (vi)ver a experiência do outro. Cf. SANTIAGO, Silviano. Nas malhas da letra. São Paulo: Companhia das Letras, 1988.
} 
envolvem, o livro de Bonassi opera com fragmentos e cacos, movendo limites. Daí que valha como um passaporte, que permite a travessia de fronteiras e não seu borramento. As fronteiras existem, não há como idealizar o fim da diferença entre centros e periferias, o que se pode é buscar a validação de passaportes que permitam o trânsito dos cidadãos. Resta saber quantos terão acesso a ele: o livro e o documento.

\section{A4}

\section{A B STRACT}

This study is an investigation of the role of the urban narratives in the representation of social exclusion. It analyses Fernando Bonassi's Passaporte, discusses the genre itself, as well as Ricardo Piglia's theory of the short story and his rereading of Ítalo Calvino's Six Memos for the Next Millennium in a recent article.

\section{KEY WORDS}

Fernando Bonassi, urban narratives, social exclusion.

\section{REFERÊNCIAS BIBLIOGRÁFICAS}

AugÉ, Marc. Não-lugares: introdução a uma antropologia da supermodernidade. Trad. Maria Lúcia Pereira. Campinas: Papirus, 1994.

Bonassi, Fernando. Passaporte (relatos de viagens). São Paulo: Cosac \& Naify, 2001.

Burztyn, Marcel (Org.). No meio da rua: nômades, excluídos e viradores. Rio de Janeiro: Garamond, 2000.

De certeau, Michel. Invenção do cotidiano. Artes de fazer. Trad. Petrópolis Vozes, 1994.

Piglia, Ricardo. Teses sobre o conto. Respiração artificial. Trad. H. Jahn. Rio de Janeiro: Iluminuras, 1987.

Piglia, Ricardo. Una propuesta para el nuevo milenio. In: Margens/Márgenes. Caderno de Cultura, n. 2, out. 2001, p. 1-3.

Rodrigues, José Carlos. Higiene e ilusão: o lixo como invento social. Rio de Janeiro: NAU, 1995.

Santiago, Silviano. Nas malhas da letra. São Paulo: Companhia das Letras, 1988.

Sussekind, Flora. O Brasil não é longe daqui. São Paulo: Schwarz, 1990.

Telles, Vera da Silva. Pobreza e cidadania. São Paulo: Editora 34, 2001.

Zukin, Sharon. Paisagens urbanas pós-modernas: mapeando cultura e poder. In: Revista do Patrimônio Histórico e Artístico Nacional. n. 24, 1996, p. 205-219. 